\title{
Synthesis of New Compounds Bis-(N-Naphthal) Phthalisoimid, Bis-(N-Phenyl) Phthalisoimid and Studying Thermal Stabilty and Bio Activity
}

\author{
Marwan Mohammed F. All-Heety \\ Department of Chemistry / College of Education \\ University of AL-Anbar
}

Received

$22 / 10 / 2007$

\section{Accepted}

03 / 07 / 2008

\begin{abstract}
الخلاصة
تحضير مركبات حلقية من الصعب الحصول عليها بالطرق الاعتبادية ـ تطوير معلوماتتا

حول تحضير مركبين جديدين من (بيس فتالاميك) من تفاعل مركبات اروماتية ثنائية الامين مع المعاير

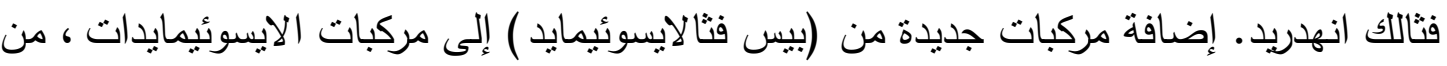
خلا إضافة كاثف (DCC) إلى بيس - فنالاميك ودراسة خصائصها الطيفية وتتخيصها طيفياً

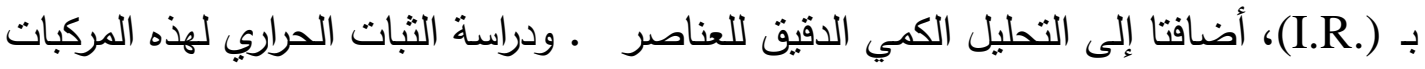
وكذلك تمت دراسة التأثير البايولوجي للمركبات المحضرة تجاه بعض البكتريا موجبة لصبغة كرام وسلبة لصبغة كرام وكذلك تجاه بعض الفطريات وبالإضافة إلى تحضير هذه المركبات فان هذه لطريقِة تعطينا عِدّة فوائد مثل نسب المنتوج الجيدِ، وطريقة عمل بسيطة في ظروف مناسبة.

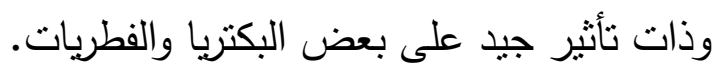

\section{ABSTRACT}

Synthesis Cyclic Compounds which are difficult to obtain in normal ways. Developing our in formation concerning the Synthesis of two new Bis-Phthalamic Compounds from reaction between diamines Aromatic Compounds with Phthalic anhydride and add new Compounds to (Compounds Isoimids) by Synthesis two new Bis-Phthalisoimids from adding reagent (DCC) to the Bis- Phthalamic and Studying and diagnosing them by Spectrally (I.R.) in addition to the accurate quantitative elemental analysis. Studying the thermal stability to yield compound and the antimicrobial activity of the synthesized compound was tested against Gram positive and Gram negative bacteria and some fungi. This method provides several advantages such as good yield, 
simple work-up procedure and environment friendly and have good effect upon some becteria and fungi.

\section{Introduction}

Isoimids Organic compounds are rare, and the difficulty of preparing in one hand, due to lack of fixity other hand ${ }^{(1)(2)}$. And Isoimids Compounds are either open or chain also indicated ${ }^{(3)}$. To Cycloisoimids, and were able to find three different ways to prepare $^{(4),(5)}$ Cycloisoimids and longer these methods (important turning point in the history of research on Isoimids) Although the method were not general, as failed to prepare saturated Cycloisoimids.

The following are general reagents in synthesis isoimids

1- Ethyl chloro format - triethyl amine

2- Tri floroacetic anhydride- triethyl amine

3- N,N-dicyclohexyl carbodiimide

The Aryl Phthalides were synthesized by one of two of major methods: acid or base ${ }^{(19)}$ catalysed reduction $\mathrm{O}-$ aroyl benzoic acid or OPhthalic acid and substituted Benzen in the Presences of cocnc. $\mathrm{H}_{2} \mathrm{SO}_{4}$ at Variable temperatures ${ }^{(19)}$.

Synthesized Bis-Phthalmic acid from reaction between two moles from Anhydrides Aromatic Compounds with Di-amines Aromatic Compounds and used it to synthesis Bis-Phthalamids Aromatic Compounds by reagent which pull one Molecular weater ${ }^{(8)}$.

\section{Instrumention:}

\section{Experimental}

1. M.P.: Electro thermal Melting Points Apparatus. Univ. Anbar, College of Sci. Dep. of Chem.

2. I.R.: Infrared Spectrophotometer, type (Philips), PU9706, Univ. Anbar, College of Sci. Dep. of Chem.

3. C.H.N.: Element Analysis, Analyzer, type 1106, carlo Eerba Univ. Mousal, College of Sci. Dep. of Chem.

Using methods in the literature ${ }^{(6),(7),(8)}$ for the preparation of these Compounds with some changes for Compounds required. The modus operandi can be divided into the following:

First step: preparation Bis- Phthalamic acid compounds:

Add gradually $(9.84 \mathrm{~g}, 0.0756 \mathrm{~mol})$ of (1,4-Diaminonaphthalene) through the suppression of separation by dissolved in $(80 \mathrm{ml}$ of Acetone $95 \%$ ) and adding (20 g, $0.1493 \mathrm{~mol}$ ) of the (Phthalic anhydride) dissolved 
(150 ml Tetrahedrofuron T.H.F.) in the form of droplets with constant stirring at room temperature. Addendum lasted (one h. and $50 \mathrm{~min}$ ) to the observing of white deposit. The process of stirring after completion of the addendum for one hour, nominated deposit of (Bis-((N-naphthal) phthalamic acid) washing re-crystallization with acetone the weight (8.2 g) per. $(83.3 \%)$ and a melting point $\left(195-196 \mathrm{C}^{0}\right)(1 \mathrm{a})$. Were diagnosed produced by Spectrally (I.R). (See Table (4)) in addition to the accurate quantitative elemental analysis.

In the same way (Bis ((N-phenyl) fathalamic acid) (1b) is preparing. (See. Table (1), Fig. (1) and (2)).
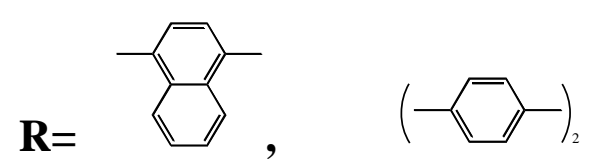<smiles>O=C(O)c1ccccc1C(=O)NPNC(=O)c1ccccc1C(=O)O</smiles>

(1)

Table (1): Characterization data for the synthesized of Bis-Phthalamic compounds

\begin{tabular}{|c|c|c|c|c|c|c|c|c|}
\hline \multirow{2}{*}{ No. } & \multirow[b]{2}{*}{$\mathrm{R}$} & \multirow{2}{*}{$\begin{array}{l}\text { formula } \\
\text { (M.Wt.) }\end{array}$} & \multirow{2}{*}{ M.P. $/ \mathrm{C}^{0}$} & \multirow{2}{*}{$\begin{array}{l}\text { Form } \\
\text { yield }\end{array}$} & \multirow{2}{*}{$\begin{array}{c}\text { Yield } \\
\%\end{array}$} & \multicolumn{3}{|c|}{ Analysis Clcd./ (Found) } \\
\hline & & & & & & $\mathrm{C} \%$ & $\mathrm{H} \%$ & $\mathrm{~N} \%$ \\
\hline 1a & & $\begin{array}{c}\mathrm{C}_{26} \mathrm{H}_{18} \mathrm{O}_{6} \mathrm{~N}_{2} \\
(454.46)\end{array}$ & $\begin{array}{l}195- \\
196\end{array}$ & $\begin{array}{l}\text { Deposit } \\
\text { yellow }\end{array}$ & 83.3 & $\begin{array}{c}68.71 \\
(67.22)\end{array}$ & $\begin{array}{l}4.00 \\
(3.87)\end{array}$ & $\begin{array}{c}6.17 \\
(5.99)\end{array}$ \\
\hline $1 \mathrm{~b}$ & & $\begin{array}{c}\mathrm{C}_{28} \mathrm{H}_{20} \mathrm{O}_{6} \mathrm{~N}_{2} \\
(480.5)\end{array}$ & $\begin{array}{l}182- \\
183\end{array}$ & $\begin{array}{l}\text { Deposit } \\
\text { yellow }\end{array}$ & 92.0 & $\begin{array}{c}69.99 \\
(69.33)\end{array}$ & $\begin{array}{l}4.20 \\
(4.01)\end{array}$ & $\begin{array}{c}5.83 \\
(4.75)\end{array}$ \\
\hline
\end{tabular}

Second step: prepare Bis- Phthalisoimids Compounds

Add $(120 \mathrm{ml})$ of dry methylne chloride $\left(\mathrm{CH}_{2} \mathrm{Cl}_{2}\right)$ to $(6 \mathrm{~g}, 0.0132$ $\mathrm{mol})$ of the (Bis ( $\mathrm{N}-$ nafthal) fathalamic acid) with continuous shaking (using Magnetic stirrer), so it forms foamy solution, then add (5 .4 g, $0.0264 \mathrm{~mol}$ ) of the detector (N: N-Dicyclohexalcarbon-diimid (DCC))(3) dissolved $(60 \mathrm{ml})$ of methylne chloride $\left(\mathrm{CH}_{2} \mathrm{Cl}_{2}\right)$ through separation funnal linked to interaction flask, and them addendum are gradually with the constant movement and cooling, the addendum lasted an hour and a half, it is observed during the formation of a white deposit, shaking lasted for three hours, after shaking lasted for a period ( 24 hours) at room 
temperature, then left to stagnate deposit, nominated solution of deposit (N: N-Dicyclohxalurea (DCU)). Taking Alerach and vapor by Evaporator spinner at room temperature, then deposit the yellow weight $(4.3 \mathrm{~g})$ and by $(71.7 \%)$ melting point $\left(97-98 C^{0}\right)(2 \mathrm{~A})$, Was diagnosing them Spectrally (I.R.) (Table (5)), in addition to the accurate quantitative elemental analysis.

In the same way been preparing the boat Bis- ((N-Phenyl) Phthalisoimid) (2B). (See. Table (2), Fig. (3) and (4)).
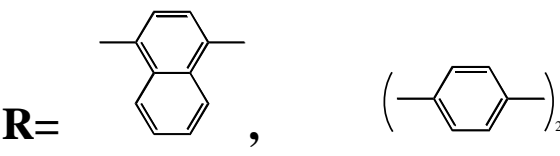<smiles>O=C1O/C(=N\P/N=C2/OC(=O)c3ccccc32)c2ccccc21</smiles>

(2)

Table (2): Characterization data for the synthesized of Bis- Phthalisoimids compounds

\begin{tabular}{|c|c|c|c|c|c|c|c|c|}
\hline \multirow{2}{*}{ No. } & \multirow{2}{*}{$\mathrm{R}$} & \multirow{2}{*}{$\begin{array}{l}\text { formula } \\
\text { (M.Wt.) }\end{array}$} & \multirow{2}{*}{$\mathrm{M} . \mathrm{P} / \mathrm{C}^{0}$} & \multirow{2}{*}{$\begin{array}{l}\text { Form } \\
\text { yield }\end{array}$} & \multirow{2}{*}{$\begin{array}{c}\text { Yield } \\
\%\end{array}$} & \multicolumn{3}{|c|}{ Analysis Clcd./ (Found) } \\
\hline & & & & & & $\mathrm{C} \%$ & $\mathrm{H} \%$ & $\mathrm{~N} \%$ \\
\hline $2 \mathrm{~A}$ & & $\begin{array}{c}\mathrm{C}_{26} \mathrm{H}_{14} \mathrm{O}_{4} \mathrm{~N}_{2} \\
(418.46)\end{array}$ & 98-97 & $\begin{array}{l}\text { Deposit } \\
\text { yellow }\end{array}$ & 71.7 & $\begin{array}{c}74.62 \\
(73.87)\end{array}$ & $\begin{array}{c}3.38 \\
(3.01)\end{array}$ & $\begin{array}{c}6.70 \\
(5.65)\end{array}$ \\
\hline $2 \mathrm{~B}$ & & $\begin{array}{c}\mathrm{C}_{28} \mathrm{H}_{16} \mathrm{O}_{4} \mathrm{~N}_{2} \\
(444.46)\end{array}$ & $89-88$ & $\begin{array}{l}\text { Deposit } \\
\text { yellow }\end{array}$ & 77.2 & $\begin{array}{c}75.66 \\
(74.54)\end{array}$ & $\begin{array}{c}3.64 \\
(2.88)\end{array}$ & $\begin{array}{c}6.30 \\
(6.05)\end{array}$ \\
\hline
\end{tabular}

\section{Thermal Stability to prepare Bis- Phthalisoimids Compounds:}

Add $(1.5 \mathrm{~g}, \mathrm{~mol})$ from Bis-((N-phenyl) phthalisoimid) in round flask of double hole and add $(15 \mathrm{ml})$ from chloroform with stirring get yellow solution, $\mathrm{CaCl}_{2}$ anhydrous tube is linked at the of linked reflux and the Nitrogen cylinder is linked with other hole, heated the reaction in water bath upon chloroform reflux $\left(60 \mathrm{C}^{0}\right)$ for $(3 \mathrm{~h}$.) with continuous stirring under Nitrogen atmosphere. Let yellow solution to cooling in room temperature. Solution evaporation under rarefied pressure and yield yellow deposit, dry it, yield compound M.P. $(88-89) \mathrm{C}^{0}(2 \mathrm{~A})$, and diagnosing them by Spectrally (IR.) it compound noticed it symmetrical with Spectrally (IR.) original compound reflux before it. Re method the using Benzene and $\mathrm{m}$-xylene in different times and all re- experiment in 
Bis-((N-naphthal) phthalisoimid)(2B) compound prepared. (See Table(3), Fig. (3) and (4)).

Table (3): Characterization data for the Thermal Stability of Bis-Phthalisoimids compounds

\begin{tabular}{|c|c|c|c|c|}
\hline No. & Solvent & Sol.C $^{0}$ & Time ref./ h. & Yield from ref. \\
\hline \multirow{6}{*}{$\mathrm{A}$} & chloroform & 60 & 3 & Bis-((N-naphthal) fathalisoimid $)$ \\
\hline & chloroform & 60 & 2 & Bis-((N-naphthal) fathalisoimid $)$ \\
\hline & Benzene & $78-80$ & 3 & Bis-((N-naphthal) fathalisoimid) \\
\hline & Benzene & $78-80$ & 2 & Bis-((N-naphthal) fathalisoimid $)$ \\
\hline & m-xylene & $138-140$ & 3 & Bis-((N-naphthal) fathalisoimid) \\
\hline & m-xylene & $138-140$ & 2 & Bis-((N-naphthal) fathalisoimid $)$ \\
\hline \multirow{6}{*}{ B } & chloroform & 60 & 3 & Bis- ((N-phenyl) fathalisoimid) \\
\hline & chloroform & 60 & 2 & Bis- ((N-phenyl) fathalisoimid $)$ \\
\hline & Benzene & 78-80 & 3 & Bis- ((N- phenyl) fathalisoimid $)$ \\
\hline & Benzene & $78-80$ & 2 & Bis- ((N- phenyl) fathalisoimid $)$ \\
\hline & m-xylene & $138-140$ & 3 & Bis- ((N-phenyl) fathalisoimid) \\
\hline & m-xylene & $138-140$ & 2 & Bis- ((N- phenyl) fathalisoimid) \\
\hline
\end{tabular}

\section{Results and Discussion} follows:

Synthesis Aromatic Bis-Phthalisoimid could be two steps, ${ }^{(10),(11)}$ as

\section{The first step preparing Aromatic Bis-Phathalamic acid:}

Got reaction two mol of aromatic anhydrides with one mol of the Compounds aromatic primary diamine to give a aromatic Bisphathalamic acid interview, and also explained the following formula.

The second step prepare Compounds aromatic Bis- Phthalisoimids:

Using acetic aromatic Bis-phthalamic acid Prepared in this research as raw materials in the preparation of Compounds aromatic Bis(phthalisoimids) or (phthalimids) interview, and that the withdrawal of two molecular water from acid Bis-fathalamic acid (and choose the type of detector user in withdrawing of two molecular water), when used acetic acid anhydride existence sodium acetic anhydride degrees when heat ranging from $\left(85-100 \mathrm{C}^{0}\right)$ is obtained Compounds from Bisphthalisoimids.

As for Compounds Bis-(Phthalisoimids) from Phthalamic acid aromatic interview, are using detector ${ }^{(4),(5),(12)}$ (Dicyclohexylcarbodiimide (DCC)) and is one of the reagents powerful withdrawal of water

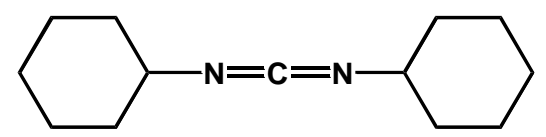

(DCC)

(3)

also explained the following formula: 


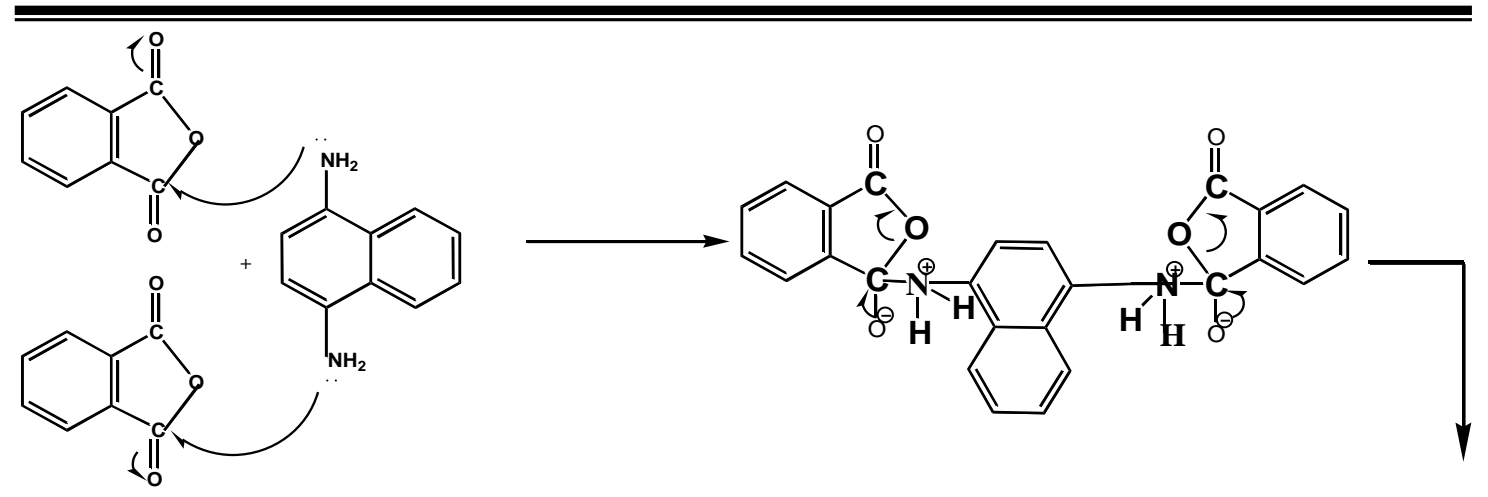<smiles>CC(C)CCNc1ccccc1C(=O)Nc1ccccc1C(=O)Nc1ccccc1C(=O)Nc1cccc2c(NC(=O)c3ccccc3C(=O)O)cccc12</smiles>

(1a)

(DCC)

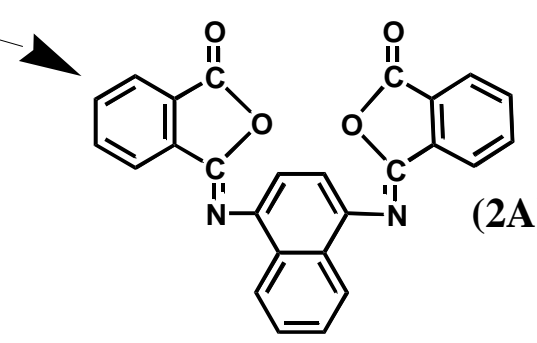

\section{Spectrum I.R. Compounds Prepared:}

Diagnosed aromatic Bis-Phthalamic acid Prepared and structures Bis-(Phthalisoimids) Prepared using infrared I.R spectrum in (KBr) disk as follows:

\section{For Bis-Phthalamic acid Prepared:}

Peak emerged strong absorption at the site $\left(3310-3300 \mathrm{~cm}^{-1}\right)^{(13)}$ Vibrated to the frequency of the bond $(\mathrm{N}-\mathrm{H})$ and the peak is very strong and broad in site (3110-3350 $\left.\mathrm{cm}^{-1}\right)$ attributed to the frequency of the bond $(\mathrm{O}-\mathrm{H})$, a peak of strong intensity at the site $\left(1450-1660 \mathrm{~cm}^{-1}\right)$ Vibrated to the frequency of the bond of stretching imid $(\mathrm{C}=\mathrm{O})(13),(14)$ and a group of beam intensity at different locations $\left(1560,1590,1610 \mathrm{~cm}^{-1}\right)$ Vibrated to the frequency stretching bond $(\mathrm{C}=\mathrm{C})$ and aromatics set of beams in sites $\left(790,850 \mathrm{~cm}^{-1}\right)^{(11)}$ Vibrated to the frequency of bond angle (C-H) outside the workshop. (See Table (4), Fig. (1) and (2)).

Table (4): IR. Spectra of Bis-Phthalamic acid Prepared

\begin{tabular}{|c|c|c|c|c|c|c|c|c|}
\hline NO. & $\begin{array}{c}\boldsymbol{N}-\boldsymbol{H} \\
\mathrm{cm}^{-1}\end{array}$ & $\begin{array}{c}\boldsymbol{C = O} \\
\mathrm{cm}^{-1}\end{array}$ & $\begin{array}{c}\mathrm{O}-\mathrm{H} \\
\mathrm{cm}^{-1}\end{array}$ & $\begin{array}{c}\mathrm{C}-\mathrm{N} \\
\mathrm{cm}^{-1}\end{array}$ & $\begin{array}{c}\mathrm{C}-\mathrm{O} \\
\mathrm{cm}^{-1}\end{array}$ & $\begin{array}{c}\mathrm{C}=\mathrm{C} \\
\text { aromatic }\end{array}$ & $\begin{array}{c}\mathrm{C}-\mathrm{H} \\
\text { Out of plane }\end{array}$ & $\begin{array}{c}\mathrm{C}=\mathrm{O} \\
\text { amide }\end{array}$ \\
\hline \hline $\mathrm{a}$ & 2900 & 1700 & $3100-3225$ & 1300 & 1210 & $1560-1610$ & 790 & 1450 \\
\hline $\mathrm{b}$ & 2920 & 1690 & $3110-3300$ & 1320 & 1210 & $1590-1440$ & 850 & 1660 \\
\hline
\end{tabular}




\section{As for the Compounds Bis -Phthalisoimids Prepared:}

Showed some differences in the type and location bond when compared with Bis-Phthalamic acid as follows:

since disappeared frequency absorption of a two $(\mathrm{O}-\mathrm{H}),(\mathrm{N}-\mathrm{H})$ and Compounds belonging to Bis-fathalamic acid, emerged a powerful new peak distress at the site $\left(1580-1590 \mathrm{~cm}^{-1}\right){ }^{(13),(15)}$ attributed to the frequency seismic vibration symmetry $(C=N)$. The package of strong intensity in the region $\left(1660,1650 \mathrm{~cm}^{-1}\right)(11)$ and the frequency of sustained analog seismic $(\mathrm{C}=\mathrm{O})$. (See Table (5), Fig. (3) and (4)).

Table (5): IR. Spectra of Bis-Phthalisoimids Prepared

\begin{tabular}{|c||c|c|c|c|}
\hline NO. & $\mathrm{C}=\mathrm{O} \mathrm{cm}$ & $\mathrm{C}=\mathrm{C}$ aromatic & $\mathrm{C}-\mathrm{H}$ & $\mathrm{C}=\mathrm{Ncm}^{-1}$ \\
\hline $\mathrm{A}$ & 1660 & 1440 & 3250 & 1590 \\
\hline $\mathrm{B}$ & 1650 & 1420 & 3250 & 1580 \\
\hline
\end{tabular}

\section{Biological activity}

All Bis-Phthalisoimids (2A and 2B) prepared compounds were screened for their antimicrobial activity against ${ }^{(16)(17)}$ the Gram-positive bacteria (1-Staphylococcus aureu, 2-Bacillus subtilis, 3-Bacillus cereus), Gram-negative bacteria (4-Psedomonase aeruginosa, 5- Esherichia Coli), as well as fungi: a) Aspergllus niger, b) penicillium italicum, C) fusarium oxysporum. Standard antibiotic drug Amoxicillin for bacteria were used at a concentration of $(0.1,1,10,20) \mathrm{mg} / \mathrm{ml}$ and Mycostatin for fungi were used at a concentration of (1000 ppm) for comparisons. The biological activity for these compound have been evaluated by filter paper disc method $^{(16)}$ after dissolved in N,N-dimethyl formamide to obtain a $1 \mathrm{mg} / \mathrm{ml}$ solution $(1000 \mathrm{ppm})$. The inhibition Zones of microbial growth surrounding the filter paper disc $(5 \mathrm{~mm})$ were measured in millimeters at the end incubation period of 3 days at $37 \mathrm{C}^{0}$ for Esherichia Coli and $28 \mathrm{C}^{0}$ for other bacteria and fungi, N,N-dimethyl formamide alone showed on inhibition zone. The results are illustrated in. (See. Table (6)).

Table (6): Antibacterial activity of the synthesized compounds

\begin{tabular}{|c|c|c|c|c|c|c|c|c|c|}
\hline \multirow{2}{*}{ Comp. } & \multirow{2}{*}{$\begin{array}{l}\text { Con. } \\
\mathrm{Mg} / \mathrm{ml}\end{array}$} & \multicolumn{8}{|c|}{ Organism $^{*}$} \\
\hline & & 1 & 2 & 3 & 4 & 5 & $\mathrm{~A}$ & $\mathrm{~B}$ & $\mathrm{C}$ \\
\hline \multirow{4}{*}{ A } & 0.1 & 22 & 27 & 16 & 24 & 20 & 14 & 17 & 22 \\
\hline & 1 & 28 & 22 & 19 & 18 & 12 & 12 & 15 & 10 \\
\hline & 10 & 10 & 25 & 14 & 20 & 9 & 14 & 18 & 20 \\
\hline & 20 & 26 & 16 & 22 & 13 & --- & 16 & 18 & 18 \\
\hline \multirow{4}{*}{ B } & 0.1 & 17 & 18 & 13 & 9 & $\begin{array}{c}-- \\
\end{array}$ & 15 & 16 & 22 \\
\hline & 1 & 25 & 20 & 12 & 6 & 11 & 13 & 22 & 16 \\
\hline & 10 & 25 & 20 & 10 & 10 & 19 & 13 & 17 & 16 \\
\hline & 20 & 20 & 12 & 23 & 11 & 22 & 16 & 12 & 10 \\
\hline Amoxicillin & \multirow{2}{*}{$\begin{array}{l}1000 \\
\text { ppm }\end{array}$} & 29 & 20 & 12 & 26 & 10 & & & \\
\hline Mycostatin & & & & & & & 12 & 19 & 25 \\
\hline
\end{tabular}

Organism*: 1- Staphylococcus aureu. 2- Bacillus subtilis. 3- Bacillus cereus. 4- Psedomonase aeruginosa. , A- Aspergllus niger. B-penicillium italicum. C- fusarium oxysporum. 


\section{REFERENCES}

1. Curtin D. Y. and Miller L. L.; (1965). Tetrahedron; 23, 1869.

2. Boral-Koshlcs, B. A. (1934). Trans. Lenlngrad. Chem. Tech Inst 1, 135-147 (Cf . Chem. Abst, 29, 8590² (1935).

3. Cotter R. J., Sauers C. K., and Whelan J. M., (1961). J. Org. Chem.; 26,10 .

4. Sauers C. K. and Cotter R. J. (1961). J., Org. Chem., 26,8.

5. Kennedy R. O. and Thomes R. D., (1997), Counarins: Biology Applications and Mode of Action, Wiley and Sons.

6. M.L. Sherrill, Schaeffer F.L., and Shoyer E.P, , (1928).J. Amer. Chem. Soc.; 50,474.

7. Colson J. G., Mlchel R. J., and Paufler R. M.; (1966). J. Polumer Scl.; A-1, 4(1), 59.

8. All-Heety M. M., (2005). Synthesis some aromatic Bis-imides compounds and studying their Bio activity, Agrar. Sci., 282-295.

9. Tsuo K. C., Barrent R. J. and Seligmna A. M., (1988). J. Amer. Chem. Soc; 77, 4631.

10. Li C. J. and Chan T. H, (1997). Organic reactions in aqueous media, Wiley, New York,.

11. Anastas P and Williamson T, Green (1998). Chemistry, Frontiers in Benign ChemicalSynthesis and Procedures, Oxford Science Publications.

12. Katritzky A.R. and Richard D. Tarr. (1988). J. Polym. Sci. Part(A), Polym. Chem., 26(12), 3323.

13. Hoogewerff S. and Van W. A., (1982). Dorp., Rec. trav. Chem.; 11, 84.

14. Balaban A. T., Schroth W. and Fischer G. (1969). Advances in Heterocyclic Chem., (ed. Katritzky A. R. and Balaban A.T.), Vol. 10, P.241-326, Academic Press.

15. Hine J., (1952). Physical Org. Chem., Mc Graw.; Hill Book Co., Inc., New York, N. Y., P.268. 
16. Nofal Z. M., EL-Zahar M. and Abd ELKarim S. (2000), Novel derivative with expected biological activity, Molecules, 5: 99-113.

17. Vandepitte J., Engbaek K., Piot P.and Heuck C. C., (1991). Basic Laboratory Procedures in Clinical Bacteriology., world health Organization Genova

18. Nene Y. L., and Thapliyal P. N., (1982), fungicides in Plant disease control, Oxford and IBH Publ. New Delhi, P. 192.

19. AL-Hamdny R., Bu-Irqaiq M. A. (1989). (Condenation of OPhthalaldehydic acid with Disubsti: uted benzene, 3-Aryl Phthalides II) I. J. of Chem. Vol. 14, No.(2), P- $48-50$. 


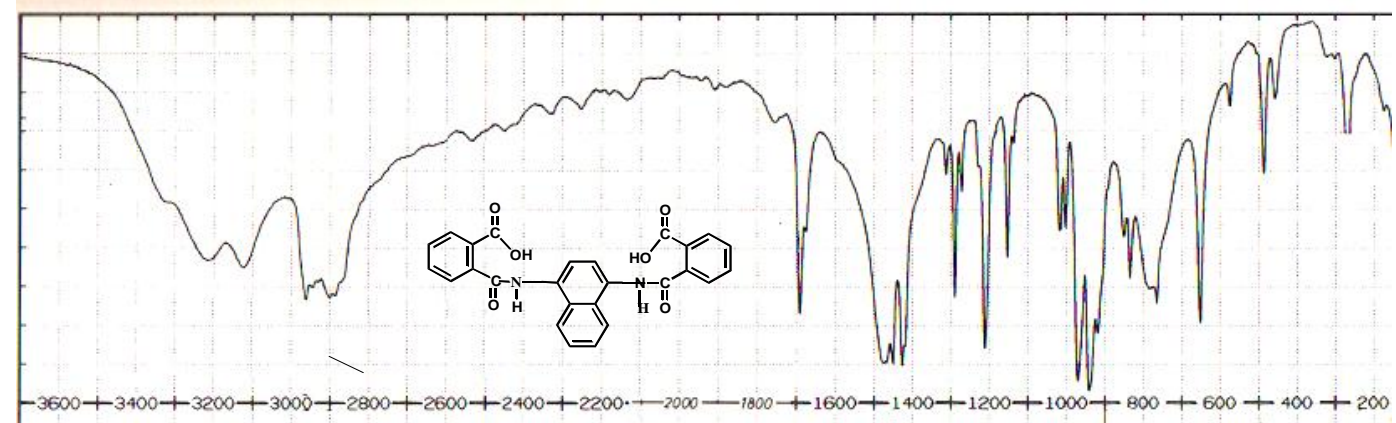

Fig. (1): Spectrum IR. For Comp.( 1a).

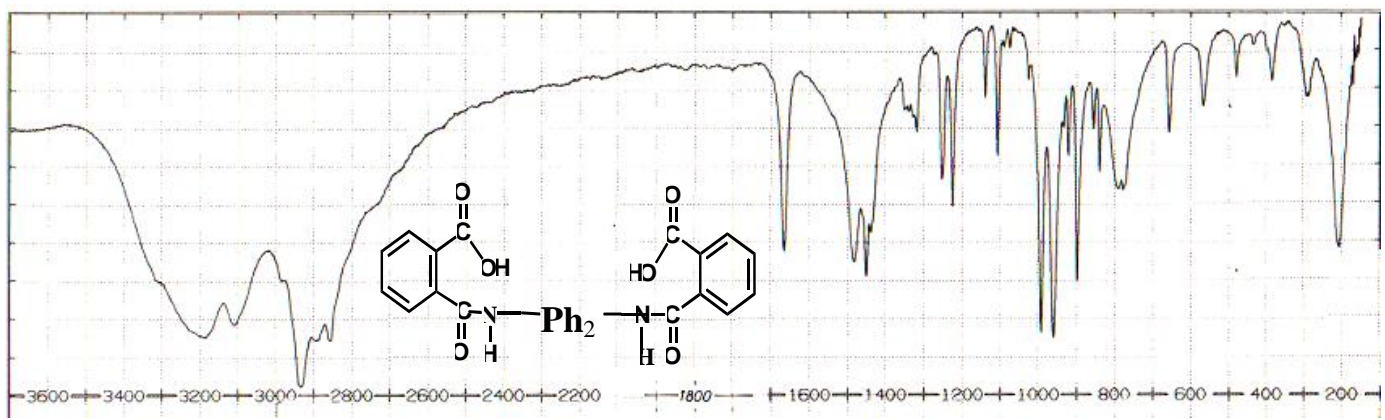

Fig. (2): Spectrum IR. For Comp.( 1b).

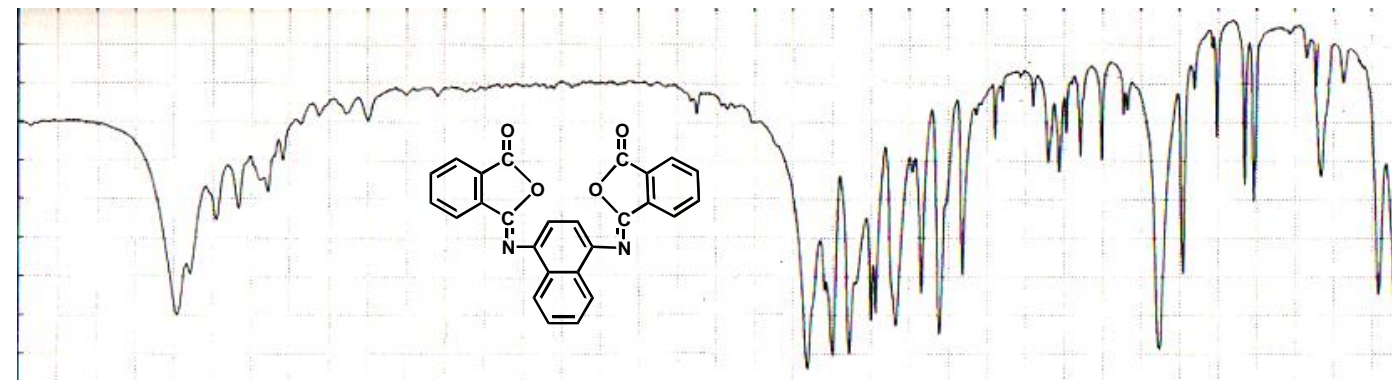

Fig. (3): Spectrum IR. For Comp.( 2A).

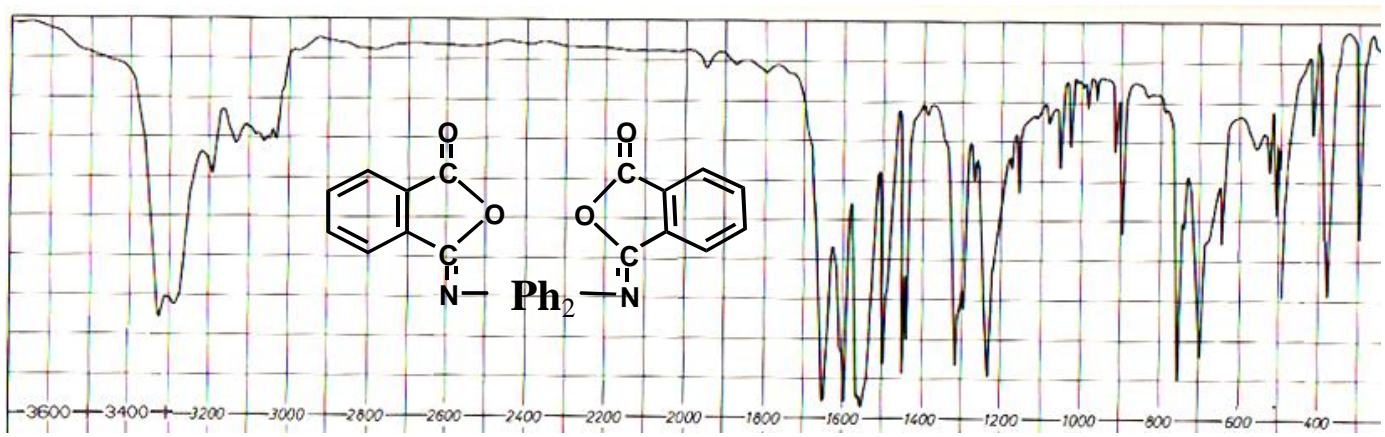

Fig. (4): Spectrum IR. For Comp.( 2B). 